Language - Culture - Politics, Vol. 1/2021

ISSN 2450-3576

e-ISSN: $2719-3217$

DOI: $10.54515 /$ lcp.2021.1.99-116

\title{
Magdalena Bojar
}

State School of Higher Education, Chełm (Poland)

ORCID: 0000-0001-6014-2383

\section{Teaching English in preschool age - selection of methods and techniques}

\section{Nauczanie angielskiego $\mathrm{w}$ wielu przedszkolnym - dobór metod i technik}

\begin{abstract}
The main purpose of this article is to present methods and techniques that can be used in the process of teaching a foreign language at preschool age. The first aspects to be addressed are developmental features of children, such as mechanical memory, short attention span, emotions and physiology of brain. The following issue described in the article refers to conventional methods, such as the Direct Method and the Audiolingual Method. The third part is devoted to unconventional methods, such as the Natural Approach, CLT, the Spiral Language System, as well as methods based on action (TPR), or - observation and words. They are supported by interesting techniques that are considered key factors in the discussed topic.
\end{abstract}

Key words: attention span, projects, stories, theme charts, tongue twisters, drama, riddles, CLT, TPR.

\section{Abstrakt}

Głównym celem tego artykułu jest prezentacja metod i technik, które można wykorzystać w procesie nauczania języka obcego w wieku przedszkolnym. Pierwszym poruszonym aspektem są cechy rozwojowe dzieci, takie jak pamięć mechaniczna, 
krótki okres koncentracji, emocje czy cechy fizjologiczne mózgu. W dalszej części zostały opisane metody konwencjonalne, np. metoda bezpośrednia oraz metoda audiolingwalna. Trzecia część jest poświęcona metodom niekonwencjonalnym, takim jak: podejście naturalne, metoda komunikacyjna CLT, Spiralny System Językowy, metody oparte na działaniu (TPR), obserwacji i słowie, które zostały wsparte ciekawymi technikami będącymi kluczem do sukcesu w obrębie omawianego tematu.

Słowa kluczowe: krótki okres koncentracji, projekty, opowiadania, karty tematyczne, łamańce językowe, drama, zagadki, CLT, TPR.

\section{Introduction}

Nursery school is regarded as a place which exerts a great influence on shaping children's personality. Those aged 3-6 evince a natural curiosity about the world and willingness to learn and yet, predispositions such as inquisitiveness, eagerness to discover the unknown, and the ability to imitate are significant in the process of English language teaching. This is confirmed by the fact that preschool children tend to ask a large number of questions. Their content is extremely rich and varied and concerns many subjects, phenomena and issues because youngsters, first and foremost, acquire knowledge precisely through questions; they strive to obtain pieces of information that engross them. For this reason, it is beneficial to teach the English language at an early age because the younger the child is, the easier and more natural the process becomes. Moreover, bringing children into contact with a foreign language in nursery school gives them a chance to gain a positive experience in a new field and thus, develops motivation to master it in later school education. However, teaching children can only be successful if certain developmental features are taken into consideration. Komorowska (1999, pp. $42-44)^{1}$ sets forth the most significant ones which guarantee success in gaining linguistic competence.

First of all, she emphasizes the fact that children are characterized primarily by concrete thinking and mechanical memory. Abstract thinking and logical memory, which appear only in adolescence, are not yet developed. Accordingly, it means that teachers should implement names of specific objects which are within sight, situations and people that can be easily recognized and identified, examples of simple, meaningful and authentic commands and

\footnotetext{
${ }^{1}$ All excerpts selected from Komorowska, H. (1999). Metodyka Nauczania Języków Obcych. Warszawa: WSiP are translated by the author of the article.
} 
phrases like I have..., I know..., I want.... Similarly, Harmer (2003, p. 38) states that: "they [children] ... learn indirectly rather than directly - that is they take in information from all sides, learning from everything around them... . Their understanding comes from... what they see and hear and, crucially, have a chance to touch and interact with". Also, Brown (2001, p. 89) suggests introduction of sensory aids as they "help children to internalize concepts. The smell of flowers, the touch of plants and fruits, the taste of foods, ... are important elements in children's language teaching".

Secondly, Komorowska draws attention to another important issue, i.e. children tend to forget newly introduced material quickly even though they learn it really fast. Moreover, they "have a limited attention span; unless activities are extremely engaging they can easily get bored, losing interest after ten minutes or so". (Harmer, 2003, p. 38) Therefore, according to Komorowska teachers should organize attractive and varied multiple repetitions, for example: enumerate brown animals, enumerate animals that live in Africa, enumerate animals that you saw, enumerate animals that start with the letter $B$; activities should be kept short and frequently changed; a variety of attention-enhancing stimuli is also necessary, i.e. picture, sound, movement, hence the usefulness of singing, movement games, viewing and colouring pictures, cutting out or gluing for children need various forms of theatrical, artistic and musical expression. This view is also supported by Brown (2001, p. 89), who claims that "projects and other hands-on activities go a long way toward helping children to internalize language. Small-group science projects, for example, are excellent ways to get them to learn words and structures and to practice meaningful language".

Last but not least aspect that Komorowska mentions, refers to very strong emotional reactions which feature children. Compared with adults, they are extremely sensitive, much more fragile and spontaneous. For this reason, teachers should help their young students to overcome probable barriers in terms of learning English language. The most important factor is a kind, warm and inviting mentor who creates a nice and safe atmosphere in the classroom environment. In addition, he should accept the fact that children may show enthusiasm, expressiveness and eagerness on one occasion or boredom, resentment and fatigue on the other (obviously, in such situations teachers should react immediately by changing activities, topic or groupings). Also, he should implement elements of humour and comedy in his English lessons. In this case comics, picture stories, cartoon jokes and scenes appear to be very helpful. However, under no circumstances should a teacher ridicule his students' mistakes or failures or allow other pupils to 
do so. "Children's egos are still being shaped, and therefore the slightest nuances of communication can be negatively interpreted. Teachers should be patient and supportive to build self-esteem as children are often innovative in language forms but still have a great many inhibitions". (Brown, 2001, p. 89) Moreover, Wieszczeczyńska (2000, p. 6) $)^{2}$ draws attention to the physiological features of children that favour teaching English at a younger age. She uses data from Penfield, Roberts and Lennenberg, neuroscientists who studied the physiology of brain. They claim that the best time to learn a foreign language is in the first ten years of a child's life, and that after the age of ten, the brain becomes less plastic. Therefore, the child is able to learn it naturally and without too much difficulty.

When planning English language lessons at the age of 3-6, the key to success, of course taking into account the above-mentioned features, is the selection of appropriate methods and techniques due to which teachers are able to achieve their goals. And this is the subject of a further elaboration in this article.

\section{Conventional Method}

\section{The Direct Method}

The first method that English teachers can use in working with children is a conventional method known as the Direct Method. It recognizes the ability to conduct oral exchanges as the main goal of learning, which is why it is often considered the conversational method. It emphasizes the use of a foreign language, thus eliminating the mother tongue. Therefore, children get to know and perceive the world only in a studied language. In addition, teachers introduce only everyday vocabulary and sentences, organize question-answer exchanges, and employ modelling and practice of new teaching points. In order for the students to understand the material or remember new vocabulary, teachers use objects, pictures as well as refer to demonstration or association of ideas. Another features dedicated to this method are: inductive teaching of grammar, emphasis of correct pronunciation, and development of listening and speaking skills. (Richards, Rogers, 1986, pp. 9-10) Additionally, as the name of the method suggests, "second language learning should be more like first language learning - lots of oral interaction, spontaneous use of the language, no translation between first and second languages, and little or no analysis of grammatical rules". (Brown, 2001, p. 21)

\footnotetext{
${ }^{2}$ The excerpt selected from Wieszczeczyńska, E. (2000). „Dlaczego warto rozpoczynać naukę języka obcego w okresie wczesnoszkolnym?". In: Czasopismo dla nauczycieli. Języki: obce w szkole, 6 (12). Warszawa: CODN is translated by the author of the article.
} 


\section{The Audiolingual Method}

Another conventional method that can be used in working with children is the Audiolingual Method, which aims to master the four language skills in the sequence from listening and speaking to reading and writing. In this method, mastering a foreign language means developing appropriate habits based on stimulus and response connections. The language habit is developed mechanically, without reflection, through repetition, analogy, remembering and consolidating the practiced material. Students listen to recordings or sentences uttered by the teacher and then repeat. The teacher may also use stimuli, e.g. a picture at the beginning of sentence presentation or one word suggesting the content of the statement, in order to elicit an intended linguistic response. If correct, the learner is praised, i.e. receives a feedback reinforcement. Multiple repetitions and memorization of sentence patterns are done in order to avoid the appearance of any linguistic error, which in the Audiolingual Method is a manifestation of interference, i.e. the negative influence of the mother tongue. And, for this reason, it is thoroughly eliminated. In addition, any explanations and grammatical comments as well as analysis of the linguistic material are also rejected. All in all, the method is based on memorization and role playing. (Komorowska, 1999, p. 28)

\section{Unconventional Method, Approaches and Techniques}

\section{The Natural Approach}

The Approach is based on the assumption that the so-called meaningful exposure is decisive for the mastery of a foreign language. This means that the general meaning of statements uttered in English is easily comprehensible to young learners, because they are embedded in well-known contexts. The validity of this thesis is justified by the fact that this is precisely the way all children learn their mother tongue effectively. For this reason, the teacher's task is to provide as many natural, meaningful, interesting statements supported by mimicry and gestures as possible yet simple and understandable. In addition, he ought to create an atmosphere of security and acceptance, as this approach is based on the belief that the key to successful learning is to eliminate stress and ensure a sense of security. Therefore, the teacher does not force the children to talk unless they choose to do so. He does not correct mistakes either, but continues the conversation in order to maintain contact. During the conversation, he utters the correct forms many times, remembering at the same time that the statements should be at a slightly higher level than the one represented by the student, as it stimulates development. This approach is high- 
ly recommended for teaching children English because it focuses both on speaking and most of all - on listening. (Komorowska, 1999, pp. 32-33)

\section{Communicative Language Teaching (CLT)}

Here, in this approach the aim of learning is to achieve communicative competence which enables spontaneous and uninhibited exchange of thoughts, ideas, opinions or remarks in various everyday life situations. Activities should reflect a genuine communication, hence the need for the multitude of dialogues, simulations, role plays, games, discussions or debates rehearsed in pairs and groups. The main reason is that Communicative Language Teaching is not about learning language as a system, but about the ability to send and receive information successfully. Therefore, it aims at fluency, effectiveness and appropriateness of the message, but not at grammatical correctness. Moreover, the presentation of new material should be contextualized; the use of the mother tongue is limited to the necessary minimum; and finally, translation is only permitted in situations where young students need or benefit from it. (Richards, Rogers, 1986, pp. 67-68)

\section{Spiral Language Systems}

Rubak (2013, p. 101) ${ }^{3}$ presents a slightly different division of methods. She refers to Claire Selby, who, based on her own experience and research, developed the so-called Spiral Language Systems. It relies on the modal abilities of children, i.e. listening, looking and acting whereas learning process is composed of six stages:

1) Sounds: songs, cartoons, dialogues, nursery rhymes and word games;

2) Pictures: picture cards, animations, picture stories, illustrated nursery rhymes, interactive images;

3) Interest: the way to arouse interest in children is to refer to issues that are close to them and appropriate to their age, especially the ones that appeal to emotions and sense of humour;

4) Repetition: consolidation of material is essential part of effective learning. Each well-designed language course should be supplied with revision exercises which combine newly introduced items with the ones already acquired;

5) Actions: this stage assumes a blend of language learning and movement. It involves fine motor skills (activities related to the use of fingers and hands) and high motor skills (mobility of the whole body);

\footnotetext{
${ }^{3}$ The excerpt selected from Rubak, A. (2013). „Metodyka nauczania języka angielskiego w kształceniu zintegrowanym". In: Czasopismo dla nauczycieli. Języki: obce w szkole, 1 (03). Warszawa: FRSE is translated by the author of the article.
} 
6) Links: similarly to repetition, it consists of building a network of connections of what is already known and comprehensible with what is newly presented.

Each of the listed stages has an assigned set of exercises. Since children have a short attention span, it results in a variety of methods (1-6) implemented during one lesson. Usually these are: Sounds, Pictures, Repetition, and Actions. At the beginning of each lesson, when children are not concentrated enough, the first three are introduced in order to calm them down. Then comes the time for Actions to get children enliven. In the last stage, the teacher re-introduces the learners to a more relaxed course of a lesson. Moreover, English classes should start and end in a familiar way so as to restore order and create a sense of security among children. Thanks to these treatments, they know when a lesson begins and when it ends. Such repeatable stages are called rituals. These are, for example: greetings, goodbyes, checking the attendance list, writing down the day and date, sticking the current weather forecast and naming it. Rituals may also refer to special events: children's birthdays, preparation of ceremonies for mum, dad or grandparents. Another category of ritual is connected with sustaining discipline which may be achieved by silent recitation of a poem - to be more precise, the teacher begins and children finish. Of course, it must be a nursery rhyme known to them and always furnished with the same content. (Rubak, 2013, pp. 101-102)

\section{Methods based on actions}

\section{Total Physical Response (TPR)}

This method of language teaching is based mainly on two principles: psychomotor associations and a child language acquisition. Asher (Brown, 2001, p. 30) "noted that children, in learning their first language, appear to do a lot of listening before they speak, and that their listening is accompanied by physical responses (reaching, grabbing, moving, looking, and so forth). The TPR classroom, then, was one in which students did a great deal of listening and acting. The teacher was very directive in orchestrating a performance: the instructor is the director of a stage play in which the students are the actors".

When preparing children to participate in activities, the teacher says an instruction in English and at the same time illustrates it with movement. Children listen carefully and repeat the teacher's movement or gesture, e.g. stand up, sit down, walk to the door, make a circle, touch your head. When 
children remember movements that accompany each utterance, they react on their own to given orders without teacher's support. By using TPR techniques, the teacher can gradually expand the range of commands related to daily activities:

1) commands that require reacting with the whole body, e.g. clap your hands, jump three times, walk to Ann and shake her hand,

2) commands that require manipulation with items, e.g. open your book, put the red block on top of the green block, fold the paper in two, draw a smiling face,

3) commands related to pictures, maps, places, sounds, e.g. when the light is green cross the road, go to the kitchen corner and (pretend to) make a cup of tea, when I clap three times stand up and look at me.

The TPR facilitates the memorization of vocabulary, activates children while listening to stories in English language, singing songs or reciting poems. Using the TPR, teachers can guide their young students during simple experiments, artistic and technical works, physical and construction games or morning gymnastics. (Nicholls, 2021) ${ }^{4}$

\section{Projects}

The project method is a particularly important tool for foreign language teachers. Krawiec, Gendera, Frankowska $\left(2019\right.$, p. 11) ${ }^{5}$ claim that it is based on a team work of learners who independently initiate, plan, execute and evaluate the results of their work. They suggest that the best source for projects are situations grasped from everyday life. Besides, projects can be classified on the basis of the following criteria:

1) place criterion - indoor and outdoor projects,

2) duration criterion - short-term projects (lasting several hours or days) and long-term projects (lasting several weeks or months),

3) the division of labour criterion - projects prepared individually or in groups,

4) the criterion of the form of work - homogeneous projects (carried out by students at the same time and aimed at achieving the same goal) and diversified (leading to the achievement of different goals),

\footnotetext{
${ }^{4}$ The excerpt selected from Nicholls, K. Język angielski $w$ przedszkolu - metody $i$ formy pracy, 14.04.2016, https://www.wszpwn.com.pl/wydarzenie/jezyk-angielski-w-przedszkolu-metody-i-formy-pracy,218.html, 01.03.2021 is translated by the author of the article.

${ }^{5}$ The excerpt selected from Krawiec, M., Gendera, K., Frankowska, M. (2019). „Metoda projektu i propozycja jej zastosowania w edukacji językowej w szkole podstawowej". In: Czasopismo dla nauczycieli. Języki: obce w szkole, 1. Warszawa: FRSE is translated by the author of the article.
} 
5) structure criterion - strongly, partially and poorly structured projects that relate to the level of young students' activity and development of independence,

6) the criterion of the scope of the educational material - subject, modular and cross-curricular projects that integrate knowledge and skills from various school subjects. (Krawiec, et al., 2019, pp. 11-12)

According to the above mentioned authors, projects require commitment from both teachers and students. At the organizational stage, responsibility rests mainly on the teacher who cares for proper planning and preparation of his students' work. Besides, he should take into consideration:

1) a person or people this project is addressed to,

2) topic of a project,

3) reasons for preparing a project,

4) place of realization (home, school or both),

5) project implementation time,

6) ways of evaluation.

Moreover, the teacher should motivate his learners and support them with advice and help when necessary. However, in this type of educational activity, it does not mean that he provides ready-made answers, but encourages students to find solutions themselves. And finally, intended goals should be adjusted to learners' capabilities so as not to cause any obstacles in their thorough accomplishment.

As for the students, they are also responsible for the steps taken. For example, they define subject of a project, develop ways of solving various problems, collect information, make selection and analysis of gathered materials, and choose the form of presentation. If they work in groups, it gives them an opportunity to integrate with their colleagues, share ideas, experiences, information and find compromises. In order for a group of students to work efficiently, they should also define rules of cooperation. Finally, students should not forget about evaluation of both their actions in the process of creating a project and the final product itself. (Krawiec, et al., 2019, p. 12)

Although the project method seems to be comprehensive, complex and based on the four skills of listening, reading, speaking and writing, it can be safely applied to preschool children. It all depends on the way such activity is organized and carried out. Its form and performance are certainly not as advanced as, for example, in primary or secondary school. Nevertheless, it is worth treating projects as an interesting proposal activating children in the process of teaching the English language. An interesting formula of a project implementation that uses the senses of taste, sight, hearing, touch 
and movement is a lesson outside the classroom (a playground, a park, a zoo or forest), which, for example, may cover the following issues:

1) Safety instructions when walking in a park or forest,

2) Life of forest animals,

3) Tree research,

4) How different instruments play,

5) Soap bubbles and their shapes,

6) Recognizing things by taste or smell, blindfolded,

7) Practicing the sense of touch - playing with sensations and naming them (warm, cold, smooth, slippery, wet),

8) Creating posters about the four seasons,

9) Drawing forest and 'what the eye cannot see' (a very creative art game that stimulates the imagination),

10) Illustrating how the weather changes,

11) Drawing and cutting out shapes of objects,

12) Creating picture dictionaries from photos, organizing them and describing (Kondrat, 2015, p. 74) ${ }^{6}$.

In addition, Kondrat (2015, pp. 75-76) in her article proposes interesting techniques that are also based on action. These are as follows:

\section{Without Words}

Here, as the name suggests, children learn to communicate by showing the meaning of words pronounced by the teacher, e.g.

a) $I / m e$ - we indicate ourselves,

b) you - we indicate the other person,

c) it - we indicate the item,

d) like - we make a hug gesture,

e) help - we put hands together,

f) eat - we put hand to our mouth,

g) see - we show the eyes,

h) I like you, You see me, You and I eat or I help you sentences - children show the chosen sentence and the teacher pronounces it aloud. Then the roles are reversed, i.e. the teacher shows the picked utterance and the children guess which it is.

\footnotetext{
${ }^{6}$ Examples of topics selected from Kondrat, D. (2015). „Metody pracy z dziećmi w przedszkolu". In: Czasopismo dla nauczycieli. Języki: obce w szkole, 1 (03). Warszawa: FRSE is translated by the author of the article.
} 


\section{Ghost Train}

The children stand one behind the other, they hold the preceding person by the sides, form the train carriages and perform particular actions. Together with the teacher, they sing a song with instructions like: Put your right leg up, your left leg up, go straight, turn left, stamp your feet, say 'hoo hoo'.

\section{Magic pocket}

The teacher pretends to take an object out of his pocket, e.g. a hammer or an apple. He names the object in English language and then performs certain movements like hammering a nail or peeling an apple. In this way, he may teach children phrases and expressions in the present continuous. Then he urges young learners to follow his actions and to repeat what he says.

\section{Dance of emotions}

The teacher utters words like angry, scared and asks children to express these emotions through the dance. Then, he says happy cat, angry dog and his learners imitate movements of animals dancing in a way they think the animals would do.

\section{Methods based on observation}

Methods such as observation, description and demonstration also prove correct in English language classes. Picture cards, illustrations, posters, everyday objects, toys, plants and animals are significant for they can be used to introduce, practice or consolidate vocabulary related to a discussed topic. What is more, there is no need to translate meanings of words into the mother tongue and such associations facilitate remembering.

\section{Observation}

Introducing vocabulary with picture cards can be as follows:

1) The teacher shows a picture card, names it and, if possible, assigns a movement or gesture to it. Children repeat the movement.

2) The teacher says the word and children react with an appropriate gesture or movement.

3) The teacher points to a picture card, names it, and asks children to repeat it - softly, loudly, in a thick voice, squeaky, etc.

4) The teacher turns over individual cards one by one. Children name these without seeing a picture. 
5) Testing the memorization of vocabulary - children close their eyes. The teacher takes one picture from the set. Children name the missing card. (Nicholls, 2021)

\section{Description}

Illustrations or theme charts provide an excellent context for introducing new concepts and vocabulary, as well as consolidating content that children already know. For example, the teacher describes a situation presented in a given picture, indicates its individual elements and supports with gestures. Then he checks students' comprehension by asking questions (Nicholls, 2021) like: What animals do you see?, What do you do every day?, What season is $i t$ ? Three examples of theme charts are presented below:

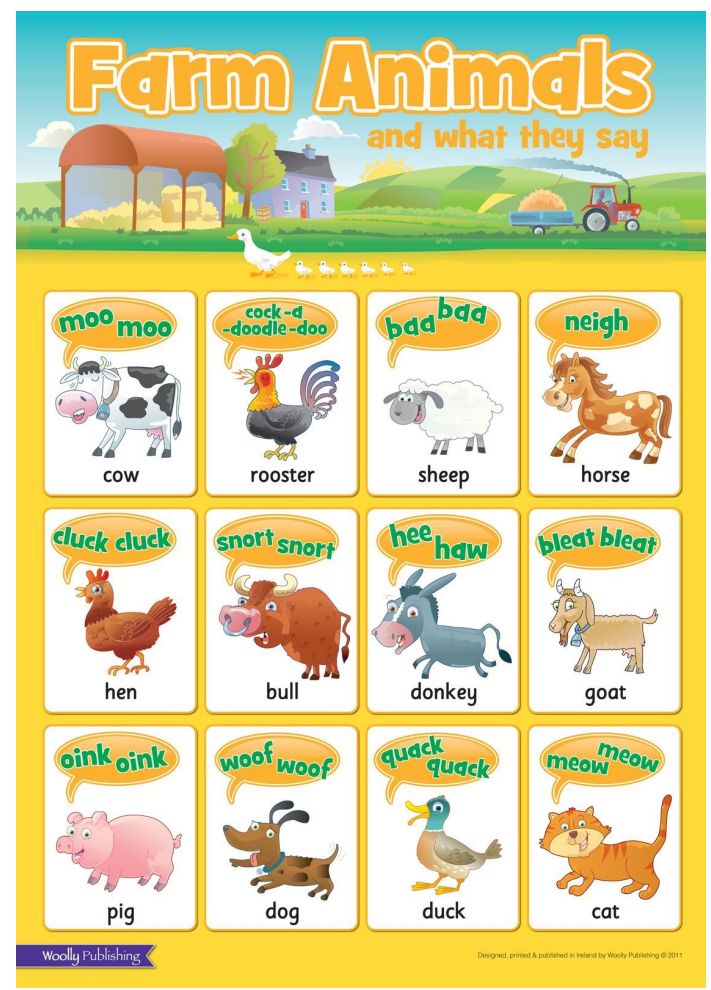

Picture 1: Thematic charts for children. Farm animals and what they say. https://www.google.com/search? source=univ\&tbm=isch\&q= thematic + charts + for + children, 13.03.2021 


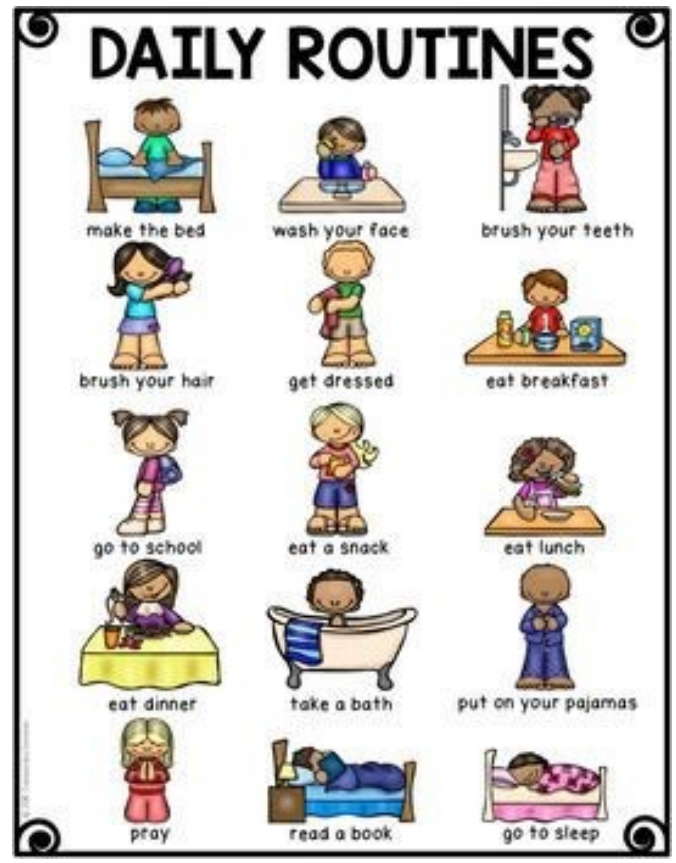

Picture 2: Thematic charts for children. Daily routines. https://www.google. com $/$ search? source $=$ univ\&tbm $=$ isch $\& q=$ thematic + charts + for + children, 13.03.2021

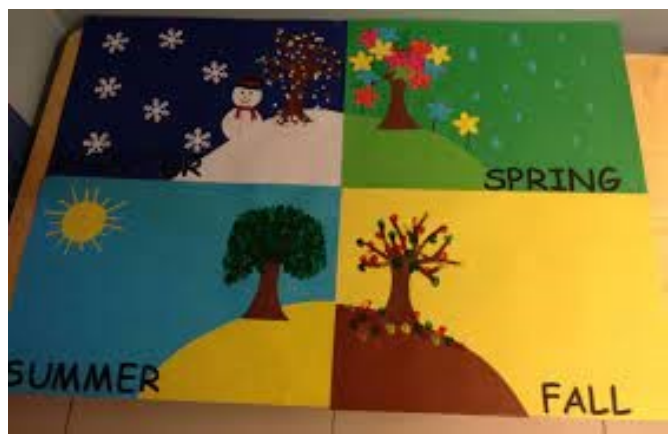

Picture 3: Thematic charts for children. Four seasons. https://www.google. com $/$ search? source $=$ univ\&tbm $=$ isch $\& q=$ thematic + charts + for + children, 13.03.2021 


\section{Demonstration}

It is a method in which TPR techniques can be used, as well as illustrations and items present in a classroom. Using these items, the teacher demonstrates a specific activity, e.g. making a sandwich or a kite, and describes each stage in English. Then he checks his young learners' comprehension by asking questions. Finally, he asks children to accomplish a task on their own, describes and comments on their actions taken in English. (Nicholls, 2021)

\section{Methods based on words}

When preparing preschool children to use the English language, teachers have many verbal methods at their disposal, such as stories, poems, songs, drama or daily communication including explanations, instructions, orders, prohibitions, contracts, etc.

\section{Stories}

Storytelling or reading short stories in a foreign language is an excellent context for introducing and consolidating typically linguistic content (vocabulary, grammar, communication functions and language skills). Preparing children for a story involves three stages:

1) Activities preceding a story - creating an appropriate atmosphere, e.g. singing a song or reciting a poem (thematically related to a story) with children, presenting characters, showing illustrations, introducing key vocabulary necessary to understand its content. The teacher can also tell a story in mother tongue or ask children about their predictions.

2) Telling or reading a story by the teacher - maintaining eye contact with children and appropriate voice modulation. Compared to their mother tongue, keeping preschoolers' attention while listening to stories in a foreign language is far more difficult. Therefore, it is necessary to consider how they can be activated. TPR techniques come in handy here, because children can illustrate storytelling with movement. In addition, they can be asked some questions related to a story or act out dialogues. It is also very important to support the story with image and sound.

3) Activities following listening to a story - in order for a story to remain in children's memory for longer, it can be used as a basis for verbal, musical or artistic expression. For instance, children can prepare a series of performances, illustrate its content with self-made drawings or talk in native language about topics covered in a story and then relate these to their own experiences. (Nicholls, 2021) 


\section{Poems and songs}

Poems and songs relating to cultural aspects of a studied language give an opportunity to broaden knowledge. Moreover, they make a great contribution to the development of speaking skills through pronunciation exercises. Also, they help to memorize vocabulary and phrases, and finally, strengthen sensitivity to rhythm and sound. Working with a poem or a song in a foreign language involves several steps:

1) Presentation of a poem/a song - during presentation, the teacher can use audiovisual materials and illustrations referring to the main theme. When it comes to choosing songs and rhymes, those that can be combined with movement are the most effective as children become participants from the very beginning, even before mastering the text. The teacher may return to a song or a poem many times in various situations, e.g. during gymnastic classes or when children perform art works. Such attitude allows them to learn a particular text gradually and in a stress-free way.

2) Common recitation of a poem/singing a song - choral repetition of a text gives children the opportunity to hear and practice pronunciation of words and phrases. Since, they use their natural imitation abilities, it does not cause major problems.

3) Using a song/a poem to work on school curriculum content - learned texts can be used in various preschool activities, e.g. during a series of performances for parents, during a trip or in thematic games. Such actions guarantee a lot of satisfaction among children and increase their motivation to learn English language. (Nicholls, 2021)

\section{Drama}

Drama techniques in foreign language teaching allow children to apply mechanically mastered language phrases and structures in staged situations. They play various roles and at the same time practice everyday life situations. Drama techniques are often used in thematic games - children like to play a hairdresser or a fire fighter. It gives them the opportunity to incorporate learned phrases and structures into their own communication repertoire (Nicholls, 2021).

Interesting techniques, in addition to those already mentioned, that can be introduced in teaching English are nursery rhymes, tongue twisters, anecdotes about animals or riddles. Here are some examples (Kondrat, 2015, pp. 72-73): 


\section{Nursery rhymes}

Example 1:

$A$ cat in the hat.

A fox in the box.

A cook with a book.

A boy with a toy.

A star on a car.

A key in the tea.

$A$ coat on the boat.

\section{Tongue twisters}

She sells seashells on the seashore.

Mix a box of mixed biscuits with a boxed biscuit mixer.

Toy boat. Toy boat. Toy boat.

Six thick thistle sticks. Six thick thistle sticks.

Good blood, bad blood.

Three free trees.

\section{Anecdotes about animals}

Why do birds fly south for the winter? Because it's too far to walk.

What goes up slowly and comes down quickly? An elephant in a lift.

What do you give an elephant with big feet? Plenty of room!

Why did the chicken cross the road? To get to the other side.

Why does everyone love cats? Because they're purr-fect!

Where do cows go with their friends? The moooovies!

\section{Riddles}

What has a face and two hands but no arms or legs? A clock.

What has a neck but no head? A bottle.

Which letter of the alphabet has the most water? The $C$.

What has to be broken before you can use it? An egg.

What begins with $T$, ends with $T$ and has $T$ in it? A teapot.

Which month has 28 days? All of the of course!

\section{Conclusion}

In conclusion, the above-mentioned methods and approaches are a great base for teaching English at an early age. Supported by a variety of techniques adapted to the preschool age, they are an excellent instrument for 
achieving educational goals. Planned activities with children should include elements of entertainment and fun. Moreover, teachers should provide a friendly atmosphere during lessons, encourage young learners, stimulate them and suggest ideas. Yet, teachers should also allow their students for independent exploration and freedom of expression. Besides, as far as activities are concerned, appropriate context is necessary as it involves understanding of the introduced words and phrases. Since children acquire language in a natural way, especially when facilitated by the teacher's appropriate intonation, facial expressions and gestures, it is recommended to introduce numerous repetitions which allow them to practise pronunciation. Needless to say, the proper selection of tools is a great support in the teaching process. Taking into consideration all the described factors, methods and techniques, it has to be stressed that their relevant implementation will result both in motivating and encouraging children to continue learning a foreign language and accomplishing intended goals by teachers.

\section{Bibliography}

Brown, H.D. (2001). Teaching by Principles. An Interactive Approach to Language Pedagogy. New York: Pearson Education.

Harmer, J. (2003). The Practice of English Language Teaching. 3rd ed., Edinburgh Gate: Pearson Education, Longman.

Komorowska, H. (1999). Metodyka Nauczania Języków Obcych. Warszawa: WSiP.

Kondrat, D. (2015). „Metody pracy z dziećmi w przedszkolu”. In: Czasopismo dla nauczycieli. Języki: obce w szkole, 1 (03). Warszawa: FRSE.

Krawiec, M., Gendera, K., Frankowska, M. (2019). „Metoda projektu i propozycja jej zastosowania w edukacji językowej w szkole podstawowej". In: Czasopismo dla nauczycieli. Języki: obce w szkole, 1. Warszawa: FRSE.

Nicholls, K. Język angielski w przedszkolu - metody i formy pracy, 14.04.2016, https://www.wszpwn.com.pl / wydarzenie / jezyk-angielski-w-przedszkolu-metody-i-formy-pracy,218.html, 01.03.2021.

Richards, J. C., Rogers, T. S. (1986). Approaches and Methods in Language Teaching. A description and analysis. Cambridge: Cambridge University Press.

Rubak, A. (2013). ,Metodyka nauczania języka angielskiego w kształceniu zintegrowanym". In: Czasopismo dla nauczycieli. Języki: obce wszkole, 1 (03).

Thematic charts for children. Daily routines. https://www.google.com/ search? source $=$ univ\&tbm $=$ isch\& $q=$ thematic + charts + for + children, 13.03.2021. 
Thematic charts for children. Farm animals and what they say. https:// www.google.com/search?source=univ\&tbm $=$ isch \& $\mathrm{q}=$ thematic + charts + for + children, 13.03.2021.

Thematic charts for children. Four seasons. https://www.google.com/ search? source $=$ univ\&tbm $=$ isch\&q $=$ thematic + charts + for + children, 13.03.2021

Wieszczeczyńska, E. (2000). „Dlaczego warto rozpoczynać naukę języka obcego w okresie wczesnoszkolnym?". In: Czasopismo dla nauczycieli. Języki: obce w szkole, 6 (12).

Correspondence concerning this paper should be addressed to Magdalena Bojar, M.A. in English Philology - a faculty member of the English and American Studies Department (The State School of Higher Education in Chetm, Poland).

E-mail:magata03@interia.pl 